\title{
Metoda waloryzacji drzew ze względu na ich wartości biocenotyczne
}

\section{Lidia Ozimkowska, Jerzy Wojtatowicz}

\section{STRESZCZENIE}

W artykule przedstawiono metodę waloryzacji drzew ze względu na ich wartości biocenotyczne. Zaproponowano opisową i liczbową ocenę wartości biocenotycznej drzewa w trzech kategoriach, które wynikają z cech osobniczych, powiązań z najbliższym otoczeniem oraz położenia w stosunku do omawianego obiektu i sąsiadujących ekosystemów. Suma punktów, jaką uzyska drzewo z trzech kategorii jest podstawą kwalifikacji do jednej z grup wartości biocenotycznej.

Słowa kluczowe: architektura krajobrazu, dendrologia, waloryzacja, wartości biocenotyczne drzew, powiązania przyrodnicze

\section{Wprowadzenie}

Drzewa oceniane są pod wieloma względami w zależności od celu, jaki ma być osiągnięty. Dlatego też niektóre z nich są oceniane, jako drzewa szczególnie ważne. Aby z drzewostanu wybrać te drzewa, które mają szczególną wartość, należy przeprowadzić różnego typu inwentaryzacje. W architekturze krajobrazu stosuje się różne metody, także te, którymi posługują się specjaliści innych branż. W artykule przybliżono dotychczas stosowane sposoby inwentaryzacji i oceny drzew oraz zwrócono uwagę na potrzebę rozszerzenia oceny drzew, w związku z pogarszającym się stanem środowiska przyrodniczego oraz tendencjami projektowania w ujęciu minimalistycznym. Wprowadzenie proponowanych zmian w sposobie waloryzacji drzew może przyczynić się do szerszego spojrzenia na problemy ochrony i eksponowania drzew szczególnych, co ma istotne znaczenie zwłaszcza w obiektach architektury krajobrazu.

Wartości drzew doceniane i oceniane były od zawsze ${ }^{1}$. Bogata symbolika i wartości materialne wybranych gatunków powodowały konieczność ich identyfikacji i waloryzacji, co następnie rozwijało się $\mathrm{w}$ ramach różnych dziedzin gospodarki, takich jak sadownictwo, ogrodnictwo, leśnictwo, ciesielstwo, szkutnictwo, rzeźbiarstwo i wiele innych. Drzewa rosnące w obiektach przeznaczonych do wypoczynku, powinny temu wypoczynkowi w peł-

\footnotetext{
${ }^{1}$ Ludzie odnajdowali w nich siłę, miejsce schronienia, pozyskiwania pożywienia i użytecznych materiałów, były wykorzystywane w celach leczniczych, mogły także być źródłem trucizny. Zimozielone symbolizowały nieśmiertelność, a sezonowe - odradzanie się. Chroniły przed duchami czy uderzeniami pioruna, upamiętniały ważne wydarzenia, były przedmiotem magii i kultu.
} 
ni służyć. Wypoczynek, rozumiany jako forma biernego czy aktywnego sposobu spędzania czasu, odbywa się w scenerii żywych i nieożywionych elementów. Najbardziej zauważalne z żywych elementów, głównie dzięki pokaźnym rozmiarom, są drzewa. Na miano szczególnych zasługują te $\mathrm{z}$ nich, które wyróżniają się z otoczenia pod względem plastycznym (np. forma, kolorem) czy użytkowym (np. pachnącymi kwiatami czy smacznymi owocami). Nie bez znaczenia jest także przydatność drzew dla innych żywych organizmów flory i fauny [Luniak 2016; Luniak, Węgrzynowicz 2019]. Obecnie coraz częściej dostrzegane są wartości biocenotyczne drzew [Wojtatowicz 1994, 2006], natomiast mało jest opracowań odnoszących się do drzew parkowych, a zwłaszcza opracowań metodyczno-studialnych. Próby takie podejmowane były od początku lat osiemdziesiątych, w ramach ćwiczeń terenowych ze studentami, a także w ramach prac studialnych do projektów w parkach historycznych [Ozimkowska, Wojtatowicz 2013, 2015, 2016 a, b, 2018].

By spektrum gatunków związanych z drzewami, które można obserwować w terenie przeznaczonym do wypoczynku było jak największe należy przeprowadzić rzetelna, często mozolną analizę stanu istniejącego drzew i ich otoczenia. W procesie projektowania konieczna jest świadomość konsekwencji, jakie przynoszą wszelkie zmiany.

Badanie terenowe, w celu wybrania i określenia wartości roślin mających znaczenie dla wzbogacenia biocenozy (z uwzględnieniem komfortu wypoczynkowego ludzi) powinno być jedną z podstawowych czynności jeśli chcemy, aby zachowane zostały jak największe wartości biocenotyczne. Te drzewa, które mają wysokie wartości biocenotyczne, a jednocześnie wzbudzają zainteresowanie ludzi, są ważne z punktu widzenia projektanta. Zwykle jednak mniejszą uwagę zwraca się na drzewa, które nie wzbudzają zachwytu swoją formą barwą czy innymi cechami, nawet jeśli mają wysokie wartości biocenotyczne. Rozważania na temat wartości biocenotycznych drzew podjęto, aby skierować uwagę na istotę ich występowania na projektowanych i pielęgnowanych obszarach.

\section{Cel i zakres}

Celem artykułu jest przedstawienie metody waloryzacji drzew ze względu na ich wartości biocenotyczne. Przy opracowaniu opisywanej metody zakresem objęto osobnicze cechy drzew oraz ich powiązania z otoczeniem wewnątrz i na zewnątrz projektowanego obiektu. Metodę można stosować w odniesieniu do różnych drzewostanów, szczególne zastosowanie powinna znaleźć w obiektach architektury krajobrazu, w zakresie ochrony drzew o wysokich wartościach biocenotycznych.

\section{Pojęcie roślin biocenotycznych}

Określenie to od dawna wykorzystywane jest w leśnictwie w odniesieniu do drzew. Za drzewa biocenotyczne leśnicy uznają: „drzewa żywe lub martwe, miejscowo spróchniałe, 
które charakteryzują się m.in. następującymi cechami: są drzewami dziuplastymi, o nietypowym pokroju, występują na nich dziuple, rosną: mchy, grzyby, porosty, wyróżniają się wiekiem lub rozmiarem i pokrojem w stosunku do innych drzew na tym terenie oraz stanowią pamiątkę kultury leśnej”2, a także "gatunki drzew i krzewów wprowadzane do drzewostanów w celu umożliwienia bytowania zwierząt; przyczyniają się do utrzymania i wzmocnienia korzystnych stosunków biocenotycznych oraz zdrowotności i naturalnej odporności lasu"3.



Z biegiem czasu termin "drzewo biocenotyczne" jest coraz powszechniej używany. „Drzewo biocenotyczne - wadliwe drzewa pozostawiane $\mathrm{w}$ lasach gospodarczych w celu zwiększenia różnorodności biologicznej. Drzewa biocenotyczne mogą być żywe lub martwe. Drzewami biocenotycznymi są drzewa z widoczną miejscową próchnica, drzewo dziuplaste, z gniazdem ptasim o średnicy ponad $25 \mathrm{~cm}$, drzewa w których ponad 1/3 korony jest martwa, drzewa na których występują huby lub rośliny, zwierzęta lub grzyby chronione. Drzewami biocenotycznymi są także drzewa o nietypowym pokroju lub z nietypowymi formami morfologicznymi (zdeformowane szyszki, narośle). Do drzew biocenotycznych zalicza się też drzewa będące pamiątkami kultury leśnej (okazy egzotyczne, pola doświadczalne założone przed 1945, szpalery itp.). Drzewami biocenotycznymi są też „przestoje” czyli drzewa pozostawione na następną kolej rębu. Jako drzewa biocenotyczne traktuje się też gatunki rodzime poprawiające bazę żerową zwierzyny, nektarodajne, urozmaicające krajobraz (jabłoń, grusza, czereśnia, śliwa ałycza i inne)" ${ }^{4}$.

Analizując różne źródła, w których definiowane są drzewa biocenotyczne stwierdzono, że pojęcie to odnoszone jest do gatunków chronionych, rzadkich i zagrożonych wyginięciem lub drzewo to ma znaczenie dla ich życia. Ujęcie takie jest domeną oceny wartości drzew z punktu widzenia ochrony przyrody.

W artykule za drzewa, krzewy i inne rośliny biocenotyczne, uznaje się te, które mają szczególne znaczenie dla życia i rozwoju innych organizmów. Rośliny te mogą być siedliskiem życia innych roślin, grzybów i porostów, dostarczać zwierzętom pokarmu, schronienia lub być wykorzystywane jako miejsca rozrodu czy lęgu, a także do realizowania innych potrzeb życiowych, jak np. śpiewu, bębnienia czy walk w okresie godowym. Wartość tych roślin wynika zarówno z biologicznych cech gatunku, właściwości osobniczych, jak i położenia w krajobrazie. Istotne jest zarówno najbliższe sąsiedztwo, jak i umiejscowienie w odniesieniu do sąsiadujących ekosystemów, nawet tych, znajdujących się poza granicami badanego

\footnotetext{
${ }^{2}$ https://www.encyklopedialesna.pl/haslo/drzewa-biocenotyczne-1/

${ }^{3}$ https://www.lasy.gov.pl/pl/edukacja/slownik/g/gatunki-biocenotyczne

${ }^{4} \mathrm{https} / / /$ pl.wikipedia.org/wiki/Drzewo_biocenotyczne
} 


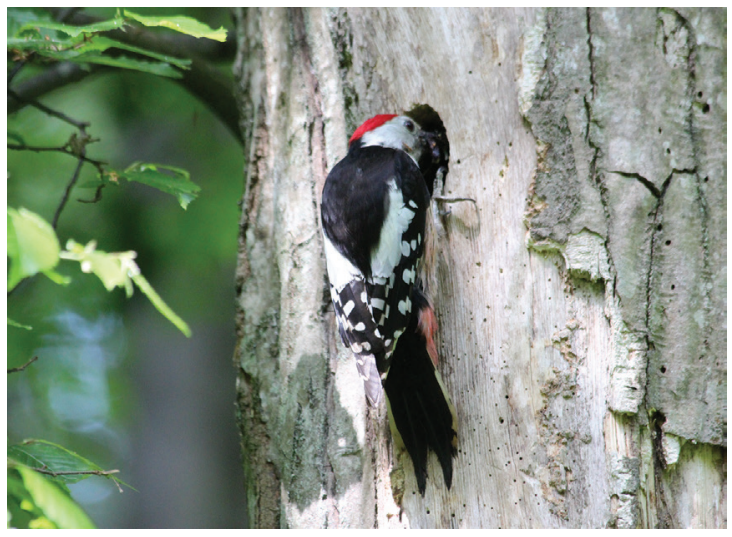

obiektu. W rozważaniach skupiono się na drzewach i krzewach, które są podstawowym tworzywem roślinnym architekta krajobrazu. Drzewa i krzewy biocenotyczne mogą zaspokajać jedną potrzebę życiową innych gatunków w ciągu krótkiego okresu lub wiele potrzeb, nawet przez wiele lat.

\section{Drzewa, które powinny być brane pod uwagę w badaniach}

Biorąc pod uwagę wartość biocenotyczną drzewa nie ocenia się wysoko jego przydatności dla jednego, nawet bardzo szczególnego organizmu, który jest zagrożony wyginięciem (co mogłoby być istotą oceny drzewa z punktu widzenia ochrony przyrody). Najważniejsze jest znaczenie drzewa jako siedliska wielu gatunków związanych z nim stale lub okresowo. Współcześnie, zwłaszcza w miastach, biocenotyczne żywe lub martwe drzewa powinny być oznaczane $\mathrm{w}$ inwentaryzacjach, w celu ich zachowania dla zwiększenia różnorodności biologicznej. Ponieważ często położenie takich drzew ma istotny wpływ na wartość biocenotyczna, a niekiedy i bezpieczeństwo użytkowników, dlatego przy ocenach ważne jest rozpatrywanie tej wartości w odniesieniu do kontekstu otoczenia. Oceniając pożyteczność określonego drzewa lub krzewu dla biocenozy można stwierdzić, że jedne dostarczają więcej pokarmu dla dużej grupy zwierząt np. owoce jarzębiny, jabłoni, inne - schronienia, inne z natury tworzą wiele dogodnych miejsc dla rozrodu, np. okazałe dęby, lipy, kasztanowce, klon pospolity odm. "Globosum” a jeszcze inne mają te cechy łącznie, np. bez czarny, winobluszcz. Cechy te jednak nie są podstawą do wyróżnienia gatunku jako biocenotycznego ponieważ nawet gatunki wydające nasiona i owoce, którymi odżywiają się zwierzęta, mogą w danym miejscu ich nie wytwarzać. Dlatego tak istotna wydaje się rzetelna inwentaryzacja drzew poszerzona o ich waloryzację z punktu widzenia biocenotycznego. Rozważając znaczenie martwych drzew w obiektach architektury krajobrazu, zwłaszcza poło-

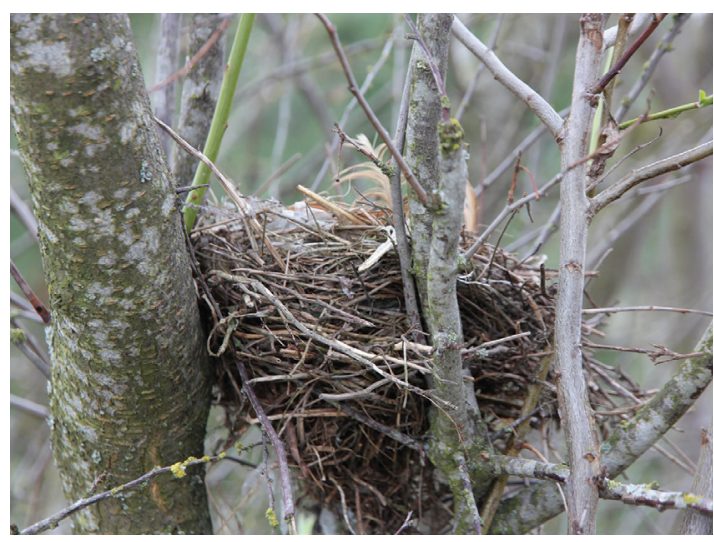


żonych na terenach miejskich lub w parkach historycznych, w których dbano, aby wszystkie martwe konary i gałęzie były usuwane, należy stwierdzić, że jeśli w ich otoczeniu nie ma leśnych rezerwatów przyrody i innych obiektów, gdzie znajduje się martwe drewno, każdy pozostawiony próchniejący pień ma duże znaczenie biocenotyczne dla życia lub osiedlania się gatunków rzadkich w tym środowisku. Nie wszystkie martwe pnie mają jednak duże wartości biocenotyczne. Także rośliny krótkowieczne, szybko rosnące i wiele światłożądnych, o stosunkowo niskiej wartości rynkowej, wprowadzanych do parku jako tzw. „przedplon" na danym etapie rozwoju parku, mogą być uznane za cenne pod względem biocenotycznym o ile spełniają opisywane wymogi. Należy zaznaczyć, że drzewa te projektowano z myślą o ich usunięciu na określonym poziomie rozwoju parku i przy podejmowaniu takiej decyzji należy ponownie określić ich wartość biocenotyczną, rozważając możliwość ich pozostawienia. Jeżeli ich zachowanie będzie zdecydowanie kolidowało z celami rozwoju par$\mathrm{ku}$, to powinny być wycięte, a ich pnie ewentualnie pozostawione do rozkładu.

\section{Funkcje roślin biocenotycznych w architekturze krajobrazu}

Dla architekta krajobrazu rośliny zwabiające zwierzęta są istotnie ze względu na wpływ jaki mają dla komfortu wypoczynku ludzi. Drzewa o dużych wartościach biocenotycznych są atrakcyjne dla wielu różnych gatunków, co w efekcie podnosi wartość rekreacyjną terenu. Wysoko ceniony, zwłaszcza w dużych miastach, jest wypoczynek polegający na obcowaniu z przyrodą. Obserwowanie korzystających

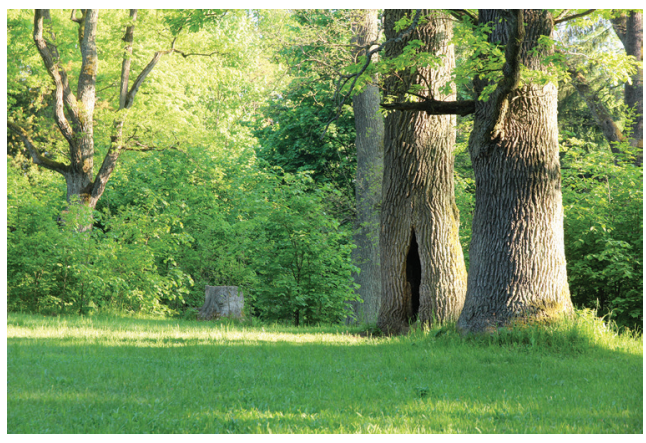
z drzew grzybów, porostów, motyli i innych owadów, gadów, płazów, ptaków czy ssaków, a także ich ruchów, wydawanych przez nie dźwięków czy innych czynności życiowych ma duże znaczenie poznawcze i najczęściej sprawia przyjemność [Ozimkowska, Wojtatowicz J., Wojtatowicz T. 2017].

Ponadto drzewa i krzewy uznane za biocenotyczne najczęściej są stare, o charakterystycznym, często malowniczym pokroju o wysokich wartościach funkcjonalnych (np. umacnianie skarp, przedplon na terenach rekultywowanych), a często także z dużymi walorami estetycznymi.

\section{Inwentaryzacja i ocena drzew w architekturze krajobrazu}

Wartość drzew w obiektach architektury krajobrazu oceniana jest pod wieloma względa$\mathrm{mi}$, np. historycznym, ochrony przyrody, a przede wszystkim bezpieczeństwa dla użytkow- 
ników, co wiąże się ze stanem zdrowotnym. W ocenie najczęściej określa się gatunek, następnie wykonuje się podstawowe pomiary dendrometryczne (obwód pnia, średnica korony i wysokość). Obwód pnia i średnicę rzutu korony mierzy się taśmą mierniczą na wysokości $130 \mathrm{~cm}$ ponad powierzchnią gruntu z dokładnością dla pnia do $1 \mathrm{~cm}$, dla korony do 0,5 $\mathrm{m}$. Wysokość mierzy się wysokościomierzem z dokładnością do 0,5 m. W czasie oględzin stanu zdrowotnego drzew i krzewów zwraca się uwagę na stan pnia (listwy martwicy, ubytki powierzchniowe i wgłębne, uszkodzenia mechaniczne, wypróchnienia, ślady żerowania owadów, ślady żerowania dzięciołów, owocniki grzybów, pochylenie pni itp.) oraz korony (susz gałęzi, połamane konary, dziuple, obecność jemioły, asymetria, redukcje).

Przy typowaniu drzew do usunięcia sprawdza się czy nie są one niszą, siedliskiem lub ostoją dla małych, ale cennych gatunków zwierząt. Czy nie mają gniazd, dziupli w których żyją zwierzęta objęte ochroną prawna, ocenia się je pod kątem zasiedlenia przez gatunki chronionych grzybów, porostów, mchów, paproci. Ogólny stan zdrowotny określa się przeważnie w skali trójstopniowej (dobry, średni, zły), gdzie:

- dobry - drzewo o prawidłowym pokroju, korona poprawnie wykształcona, niewielki susz w koronie do 20\%;

- $\quad$ średni - drzewo o nieprawidłowym pokroju, korona często zniekształcona np. ucięty przewodnik, korona jednostronna itp., możliwość występowania próchnicy, ran itp., susz 20-40\%;

- zły - drzewo o silnie zniekształconej koronie, z ubytkami wgłębnymi pni i konarów, często zamierające, susz powyżej $40 \%$.

Zamieszczone w artykule zdjęcia, autorstwa J. Wojtatowicza, prezentują przykłady drzew biocenotycznych.

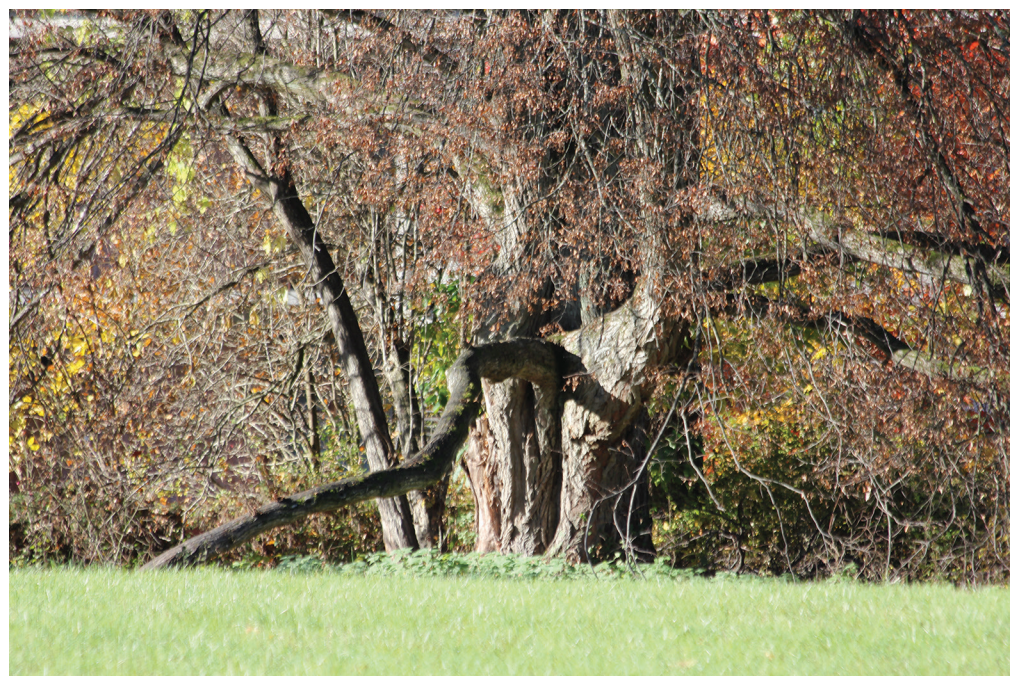




\section{Proponowana metoda oceny drzew pod względem wartości biocenotycznej w obiektach architektury krajobrazu}

Rozumiejąc złożoność problemów badawczych, jakie mogą wynikać z definicji biocenozy ${ }^{5}$ czy pojęć drzew biocenotycznych, autorzy ograniczają ocenę do drzewa i elementów łatwo zauważalnych, które są z nim ściśle powiązane. $W$ ocenie należy brać pod uwagę zależności pokarmowe i różne inne czynniki ekologiczne, łatwe do zaobserwowania w terenie, które mają aspekt praktyczny, w celu zachowania w jak największym stopniu istniejących powiązań przyrodniczych. Powinny one być uwzględnione w procesie projektowania (w tym rewaloryzacji) oraz wykorzystane $\mathrm{w}$ trakcie budowy czy wieloletniej pielęgnacji obiektu. Oceniając wartość drzew z różnych punktów widzenia zachodzi potrzeba pozostawiania najwartościowszych. Jak już wspomniano, najistotniejsze są te drzewa, które pod względem funkcjonalnym i kompozycyjnym umożliwiają realizację określonego programu wypoczynkowego, odpowiadającego na postawione cele. W parkach i ogrodach historycznych, objętych ochroną prawna, istotne jest zachowanie wartości historycznych, a jednocześnie zapewnienie jak najwyższego komfortu dla użytkowników. Podobnie, funkcje wypoczynkowe są równorzędne do funkcji przyrodniczych w większości parków ekologicznych czy dydaktycznych, w ogrodach botanicznych, zoologicznych i etnograficznych. W typowych obiektach architektury krajobrazu, jeśli drzewo ma wysokie walory umożliwiające realizację celu priorytetowego, bez względu na jego wartość biocenotyczną z pewnością zostanie zachowane.

Aby zachować drzewa o wysokiej wartości biocenotycznej należy poddać je waloryzacji. Ocena wartości biocenotycznej drzew umożliwia podejmowanie świadomych decyzji nie tylko w odniesieniu do drzew o najwyższych walorach osobniczych, lecz drzew wraz z ich otoczeniem, w którym istnieją ścisłe powiązania przyrodnicze. W opisanej niżej metodzie, na podstawie obserwacji i nasłuchu, łatwo stwierdzić czy drzewo jest martwe czy żywe, obficie owocuje, a owoce chętnie zjadane są przez różne gatunki zwierząt, ma przerzedzoną koronę, widoczne owocniki grzybów, porosty, znajdują się gniazda lub miejsca dogodne do ich zakładania, dziuple i inne miejsca do rozrodu. Po nasłuchu można poznać, czy znajduje się $\mathrm{w}$ rewirze lęgowym ptaka. Można w trakcie badań terenowych stwierdzić, jak mocno powiązane jest z otoczeniem i czy związki i zależności z elementami jego sąsiedztwa są silne czy słabe, a jego obecność wpływa na najbliższe otoczenie i biocenozę. W zaprezentowanej metodzie wyróżniono trzy kategorie oceny wartości biocenotycznej drzewa (tabele 1-3):

A - wynikająca z jego cech osobniczych (biologicznych i nabytych);

B - wynikająca z powiązań z najbliższym otoczeniem;

C - wynikająca z położenia w obiekcie i umiejscowienia w odniesieniu do ekosystemów, w tym także poza jego granicami.

\footnotetext{
${ }^{5}$ Biocenoza (gr. bios życie i koinós wspólny) - zespół populacji organizmów roślinnych (fitocenoza), zwierzęcych (zoocenoza) i mikroorganizmów (mikrobiocenoza) danego środowiska (biotopu), należących do różnych gatunków, ale powiązanych ze sobą różnorodnymi czynnikami ekologicznymi i zależnościami pokarmowymi, tworzących całość, która pozostaje w przyrodzie w stanie homeostazy (czyli dynamicznej równowagi) [Wikipedia].
} 
Ocenie podlegają drzewa żywe lub martwe. Drzewo może osiągnąć maksymalnie 3 punkty w każdej kategorii. Łącznie 9 punktów wynikających z sumowania najwyższych ocen z trzech kategorii. Minimalna łączna ocena to 3 punkty. Punkty odpowiadają ocenie opisowej i liczbowej, jaką drzewo może otrzymać podczas waloryzacji w terenie. Suma punktów, jaką uzyska drzewo jest podstawą kwalifikacji do jednej z trzech grup (I-III), gdzie: I - drzewa o najniższej wartości (3 punkty), II - drzewa o średniej wartości (4-6 punktów), III - drzewa o najwyższej wartości (7-9 punktów).

W poniższych tabelach słowo „park” używane jest symbolicznie i skrótowo, a dotyczy różnych badanych obiektów.

Tabela 1. Ocena wartości biocenotycznej drzewa, w formie opisowej i liczbowej, wynikająca z jego cech biologicznych i nabytych

\begin{tabular}{|l|c|}
\hline \multicolumn{1}{|c|}{ A - Wartość biocenotyczna drzewa wynikająca z cech osobniczych } & Punkty \\
\hline $\begin{array}{l}\text { Drzewo mało atrakcyjne jako siedlisko dla roślin, grzybów i porostów, } \\
\text { koliduje z rozwojem kształtowanej biocenozy parku. Korona przerzedzona. }\end{array}$ & \\
Brak dziupli i innych miejsc sprzyjających schronieniu, lęgom i rozrodowi & \\
zwierząt o znacznych wymiarach. Niska wartość pod względem pożytków, \\
a zwłaszcza pokarmu dla zwierząt. Gatunek zagraża faunie i florze, \\
korzystnej dla rozwoju parku, a także elementom układu kompozycyjnego.
\end{tabular}

Proponowaną metodę można rozszerzyć oceniając drzewa szczególne, dla których określenie wartości biocenotycznej jest priorytetowe na danym obszarze, np. objętym ochroną prawną pod względem historycznym lub przyrodniczym. W takim przypadku proponuje się pięciostopniową skalę ocen (tabele 4-6). Drzewo może osiągnąć maksymalnie 5 punktów w każdej kategorii. Łącznie 15 punktów wynikających z sumowania najwyższych ocen z trzech kategorii. Minimalna łączna ocena to 3 punkty. Punkty odpowiadają ocenie opisowej i liczbowej, jaką drzewo może otrzymać podczas waloryzacji w terenie. Suma punktów, jaką uzyska drzewo jest podstawą kwalifikacji do jednej z pięciu grup (I-V), gdzie: I drzewa o najniższej wartości (3 punkty), II - drzewa o dostatecznej wartości (4-6 punktów), 
III - drzewa o średniej wartości (7-9 punktów), IV - drzewa o wysokiej wartości (10-12 punktów) oraz V - drzewa o najwyższej wartości (13-15 punktów).

Tabela 2. Ocena wartości biocenotycznej drzewa, w formie opisowej i liczbowej, wynikająca z powiązań z najbliższym otoczeniem

B - Wartość biocenotyczna drzewa oceniana na podstawie powiązań Punkty z najbliższym otoczeniem

Jest jednym z elementów skupiny monokulturowej mającej niską wartość biocenotyczną. Wiele elementów otoczenia, czynniki antropopresyjne oraz prowadzone tu zabiegi pielęgnacyjne niekorzystnie oddziałują na wartość biocenotyczną drzewa i istniejące korzystne powiązania między nim a otoczeniem.

Jest jednym z elementów skupiny monokulturowej mającej średnią wartość biocenotyczną. Wiele elementów otoczenia, czynniki antropopresyjne oraz prowadzone tu zabiegi pielęgnacyjne nie wpływają znacząco na wartość biocenotyczną drzewa i istniejące korzystne powiązania między nim a otoczeniem.

Rośnie w otoczeniu o wysokiej wartości biocenotycznej. Wiele elementów otoczenia oraz prowadzone zabiegi pielęgnacyjne podwyższają wartość biocenotyczną drzewa.

Tabela 3. Ocena wartości biocenotycznej drzewa, w formie opisowej i liczbowej, wynikająca z położenia w parku i umiejscowienia w odniesieniu do ekosystemów poza parkiem

\begin{tabular}{|c|c|}
\hline \multicolumn{1}{|c|}{$\begin{array}{c}\text { C - Wartość biocenotyczna drzewa oceniana na podstawie położenia } \\
\text { w parku i umiejscowienia w odniesieniu do ekosystemów poza parkiem }\end{array}$} & Punkty \\
\hline $\begin{array}{l}\text { Drzewo oniskiej wartości biocenotycznejznajduje się w strefieintensywnejpe- } \\
\text { netracji użytkowników parku. Rośnie w centrum dużego miasta, uciążliwych } \\
\text { terenów przemysłowych, bardzo ruchliwych dróg lub na innych terenach } \\
\text { podlegających silnej antropopresji. Może być drzewem o dużych walorach } \\
\text { biocenotycznych, przez co zwabiając zwierzęta stanowi dla nich pułapkę, np. } \\
\text { obficie dostarcza atrakcyjnego pokarmu, a rosnąc w bezpośredniej bliskości } \\
\text { ruchliwych dróg stwarza zagrożenie. Z tego powodu ocenione jest jak inne } \\
\text { drzewa o niskiej wartości. }\end{array}$ & 1 \\
\hline $\begin{array}{l}\text { Drzewo o przeciętnej wartości biocenotycznej, znajduje się w strefie średniej } \\
\text { penetracji przez ludzi. Jego wartość biocenotyczna nie ma praktycznego } \\
\text { znaczenia dla ekosystemów znajdujących się poza granicami parku. }\end{array}$ & 2 \\
\hline $\begin{array}{l}\text { Drzewo o wysokiej wartości biocenotycznej znajduje się w strefie minimalnej } \\
\text { penetracji przez ludzi. Jest cennym składnikiem biocenozy parku, a w nie- } \\
\text { których przypadkach ekosystemów poza parkiem. }\end{array}$ & 3 \\
\hline
\end{tabular}


Tabela 4. Ocena wartości biocenotycznej drzewa, w formie opisowej i liczbowej, wynikająca z jego cech biologicznych i nabytych

\begin{tabular}{|c|c|}
\hline A - Wartość biocenotyczna drzewa wynikająca z cech osobniczych & Punkty \\
\hline $\begin{array}{l}\text { Drzewo bardzo mało atrakcyjne jako siedlisko dla roślin, grzybów } \\
\text { i porostów, koliduje z rozwojem kształtowanej biocenozy parku. Korona } \\
\text { przerzedzona. Brak dziupli i innych miejsc sprzyjających schronieniu, lęgom } \\
\text { i rozrodowi zwierząt o znacznych wymiarach. Bardzo niska wartość pod } \\
\text { względem pożytków, a zwłaszcza pokarmu dla zwierząt. Gatunek zagraża } \\
\text { faunie i florze korzystnej dla rozwoju parku, a zwłaszcza elementom układu } \\
\text { kompozycyjnego. }\end{array}$ & 1 \\
\hline $\begin{array}{l}\text { Drzewo mało atrakcyjne jako siedlisko dla roślin, grzybów i porostów, } \\
\text { w nieznacznym stopniu koliduje z rozwojem kształtowanej biocenozy } \\
\text { parku. Korona przerzedzona. Brak dziupli i innych miejsc sprzyjających } \\
\text { schronieniu, lęgom i rozrodowi zwierząt o znacznych wymiarach. Niska } \\
\text { wartość pod względem pożytków, a zwłaszcza pokarmu dla zwierząt. } \\
\text { Gatunek w małym stopniu zagraża faunie i florze korzystnej dla rozwoju } \\
\text { parku, zwłaszcza elementom układu kompozycyjnego. }\end{array}$ & 2 \\
\hline $\begin{array}{l}\text { Drzewo średnio atrakcyjne jako siedlisko dla roślin, grzybów i porostów, nie } \\
\text { wpływa znacząco na rozwój kształtowanej biocenozy parku. Ograniczona } \\
\text { liczba miejsc sprzyjających schronieniu, lęgom i rozrodowi zwierząt } \\
\text { o znacznych wymiarach. Gatunek niewpływający w widocznym stopniu } \\
\text { na faunę i florę korzystną dla rozwoju parku oraz elementy układu } \\
\text { kompozycyjnego. Przeciętna wartość pod względem pożytków, a zwłaszcza } \\
\text { pokarmu dla rodzimych gatunków zwierząt. }\end{array}$ & 3 \\
\hline $\begin{array}{l}\text { Drzewo atrakcyjne jako siedlisko dla roślin, grzybów i porostów, sprzyja } \\
\text { rozwojowi kształtowanej biocenozy parku. Charakteryzuje się dużą liczbą } \\
\text { potencjalnych miejsc sprzyjających schronieniu, lęgom i rozrodowi zwierząt } \\
\text { o znacznych wymiarach. Gatunek umożliwiający rozwój korzystnej dla } \\
\text { rozwoju parku fauny i flory, a także elementów układu kompozycyjnego. } \\
\text { Znacząca wartość pod względem pożytków, a zwłaszcza pokarmu dla wielu } \\
\text { gatunków zwierząt. }\end{array}$ & 4 \\
\hline $\begin{array}{l}\text { Drzewo bardzo atrakcyjne jako siedlisko dla wielu roślin, grzybów } \\
\text { i porostów. Jest istotnym elementem kształtowanej biocenozy parku. Korona } \\
\text { i pień z dziuplami, sprzyjają budowie gniazd i innych miejsc rozrodu oraz } \\
\text { schronieniu zwierząt o znacznych wymiarach. Drzewo ma wyjątkowe cechy } \\
\text { estetyczne i stanowi cenny element układu kompozycyjnego. Bardzo wysoka } \\
\text { wartość pod względem pożytków, a zwłaszcza pokarmu dla zwierząt. }\end{array}$ & 5 \\
\hline
\end{tabular}


Tabela 5. Ocena wartości biocenotycznej drzewa, w formie opisowej i liczbowej, wynikająca z powiązań z najbliższym otoczeniem

\begin{tabular}{|c|c|}
\hline $\begin{array}{c}\text { B - Wartość biocenotyczna drzewa oceniana na podstawie powiązań } \\
\text { z najbliższym otoczeniem }\end{array}$ & Punkty \\
\hline $\begin{array}{l}\text { Jest jednym z elementów skupiny monokulturowej mającej bardzo niską } \\
\text { wartośćbiocenotyczną. Wieleelementów otoczenia, czynnikiantropopresyjne } \\
\text { w tym zabiegi pielęgnacyjne, bardzo niekorzystnie wpływają na wartość } \\
\text { biocenotyczną drzewa i istniejące korzystne powiązania między nim } \\
\text { a otoczeniem. }\end{array}$ & 1 \\
\hline $\begin{array}{l}\text { Jest jednym z elementów skupiny monokulturowej mającej niską wartość } \\
\text { biocenotyczną. Wiele elementów otoczenia, czynniki antropopresyjne w tym } \\
\text { zabiegi pielęgnacyjne niekorzystnie wpływają na wartość biocenotyczną } \\
\text { drzewa i istniejące korzystne powiązania między nim a otoczeniem }\end{array}$ & 2 \\
\hline $\begin{array}{l}\text { Jest jednym z elementów skupiny monokulturowej mającej średnią wartość } \\
\text { biocenotyczną. Wiele elementów otoczenia, czynniki antropopresyjne, w tym } \\
\text { zabiegi pielęgnacyjne, nie wpływają znacząco na wartość biocenotyczną } \\
\text { drzewa i istniejące korzystne powiązania między nim a otoczeniem. }\end{array}$ & 3 \\
\hline $\begin{array}{l}\text { Rośnie w otoczeniu o wysokiej wartości biocenotycznej. Wiele elementów } \\
\text { otoczenia, w tym zabiegi pielęgnacyjne, podwyższają wartość biocenotyczną } \\
\text { drzewa. }\end{array}$ & 4 \\
\hline $\begin{array}{l}\text { Rośnie w otoczeniu o bardzo wysokiej wartości biocenotycznej. Wiele } \\
\text { elementów otoczenia, w tym zabiegi pielęgnacyjne, wyjątkowo podwyższają } \\
\text { wartość biocenotyczną drzewa }\end{array}$ & 5 \\
\hline
\end{tabular}


Tabela 6. Ocena wartości biocenotycznej drzewa, w formie opisowej i liczbowej, wynikająca z położenia w obiekcie i umiejscowienia w odniesieniu do ekosystemów poza parkiem

\begin{tabular}{|c|c|}
\hline $\begin{array}{c}\text { C - Wartość biocenotyczna drzewa oceniana na podstawie położenia } \\
\text { w obiekcie i umiejscowienia w odniesieniu do ekosystemów poza parkiem }\end{array}$ & Punkty \\
\hline $\begin{array}{l}\text { Drzewo o bardzo niskiej wartości biocenotycznej znajduje się w strefie } \\
\text { bardzo intensywnej penetracji użytkowników parku. Rośnie w centrum } \\
\text { dużego miasta, uciążliwych terenów przemysłowych, bardzo ruchliwych } \\
\text { dróg lub na innych terenach podlegających silnej antropopresji. Może być } \\
\text { drzewem o dużych walorach biocenotycznych, przez co zwabiając zwierzęta } \\
\text { stanowi dla nich pułapkę, np. obficie dostarcza atrakcyjnego pokarmu, } \\
\text { a rosnąc w bezpośredniej bliskości ruchliwych dróg stwarza zagrożenie. } \\
\text { Z tego powodu ocenione jest jak inne drzewa o niskiej wartości. }\end{array}$ & 1 \\
\hline $\begin{array}{l}\text { Drzewo o niskiej wartości biocenotycznej, znajduje się w strefie intensywnej } \\
\text { penetracji przez ludzi. Jego wartość biocenotyczna ma niewielkie znaczenie } \\
\text { dla ekosystemów znajdujących się poza granicami parku. }\end{array}$ & 2 \\
\hline $\begin{array}{l}\text { Drzewo o przeciętnej wartości biocenotycznej, znajduje się w strefie średniej } \\
\text { penetracji przez ludzi. Jego wartość biocenotyczna nie ma praktycznego } \\
\text { znaczenia dla ekosystemów znajdujących się poza granicami parku. }\end{array}$ & 3 \\
\hline $\begin{array}{l}\text { Drzewo o wysokiej wartości biocenotycznej znajduje się w strefie eksten- } \\
\text { sywnej penetracji przez ludzi. Jest cennym składnikiem biocenozy parku, } \\
\text { a w niektórych przypadkach ekosystemów poza parkiem. }\end{array}$ & 4 \\
\hline $\begin{array}{l}\text { Drzewo o bardzo wysokiej wartości biocenotycznej znajduje się w strefie } \\
\text { minimalnej penetracji przez ludzi. Jest wyjątkowo cennym składnikiem } \\
\text { biocenozy parku, a w niektórych przypadkach ekosystemów poza parkiem. }\end{array}$ & 5 \\
\hline
\end{tabular}

\section{Podsumowanie}

Opisaną wyżej metodę można zaliczyć do organoleptycznych. Jak tego typu metody, jest ona mało precyzyjna i może być też kwestionowana ze względu na trudno weryfikowalny charakter oceny. Jednak wykonana dokładnie, wyodrębnia drzewa z ich otoczeniem, o różnych wartościach biocenotycznych, co jest wystarczające w procesie projektowania. W konsekwencji pozwala na utrzymanie najwyższych, możliwych w danych warunkach, walorów biocenotycznych całego obiektu. W artykule wskazano możliwy kierunek przemian w pracach przedprojektowych. Zastosowanie praktyczne badań opisanych w treści artykułu może przyczynić się do szerszego spojrzenia na problemy ochrony i eksponowania drzew biocenotycznych w obiektach architektury krajobrazu. 


\section{Literatura}

Luniak M., 2016, Projekt "Przyroda Parku Skaryszewskiego" w latach 2014-2015 [w:] J. Romanowski (red.), Park Skaryszewski w Warszawie - przyroda i użytkowanie, Wydawnictwo Uniwersytetu Kardynała Stefana Wyszyńskiego, Warszawa.

Luniak M., Węgrzynowicz A., 2019, Wpływ renowacji parków miejskich na ich awifaunę lęgowaprzykład z Warszawy, Chrońmy Przyrodę Ojczysta, 75, 1, s. 3-15.

Ozimkowska L., Wojtatowicz J., 2013, Projekt koncepcyjny zagospodarowania "Strefy natury" w Ogrodzie Krasińskich w Warszawie, Miasto Stołeczne Warszawa - zlecenie Zarządu Terenów Publicznych ul. Podwale 23, 00-261 Warszawa.

Ozimkowska L., Wojtatowicz J., 2015, Ekspertyza dotyczaca sposobu zagospodarowania fragmentu Terenu Przy Dworze Polskim w Potworowie, zlecenie prywatne, archiwum Aster-Park.

Ozimkowska L., Wojtatowicz J., 2016 a, Ekspertyza dotyczaca sposobu zagospodarowania Parku podworskiego w Podhorcach na Ukrainie, zlecenie prywatne, archiwum Aster-Park.

Ozimkowska L., Wojtatowicz J., 2016 b, Zespót dworsko-parkowy „Willa Mindic” jako szczególny element w krajobrazie i przemiany jego struktury jako znaków czasu, MAZOWSZE Studia Regionalne, 18, Mazowieckie Biuro Planowania Regionalnego, Warszawa, s. 49-69.

Ozimkowska L., Wojtatowicz J., Wojtatowicz T., 2017, Correlations Between Birds, Plants and People in Urban Landscaping, Kaunas Forestry and Environmental Engineering University of Applied Sciences (KMAIK), Department of Landscape Architecture and Recreation, 1, 12. s. 55-68.

Ozimkowska L., Wojtatowicz J., 2018, Adaptacja założenia dworsko-parkowego w Piekartach, MAZOWSZE Studia Regionalne, 27, Mazowieckie Biuro Planowania Regionalnego, Warszawa, s. 103-121.

Wojtatowicz J., 1994, Avifauna miejskich parków historycznych [w:] Materiały Sympozjum „Dziedzictwo miejskich ogrodów i krajobrazu historycznego", Katedra Urządzania i Pielęgnowania Krajobrazu SGGW, Ośrodek Ochrony Zabytkowego Krajobrazu, Warszawa Ursynów.

Wojtatowicz J., 2006, Theorical Basis for the Biocenotical Park System [w:] Starovinnì parkì ì botaničnì badi-naukovì centri zberežennâ bìorìzznomanìttâ ta ohorona ìstoriko-kul"turnoï spadŝini. Nacìnal"na academìa nauk Ukraïni. Nacional"nij dendrologičnij park "Sofï̈vka" - NDI NAN Ukraïni. Materìali mižnarodnoï naukovoï konferenciï prisvivâčenoï 210-riččû Nacional” nogo dendrologičnogo parku “Sofiïvka” - NDI NAN Ukraïni, s. 40-46.

\section{Strony internetowe}

https://www.encyklopedialesna.pl/haslo/drzewa-biocenotyczne-1/ [dostęp 21.06.2019] https://www.lasy.gov.pl/pl/edukacja/slownik/g/gatunki-biocenotyczne [dostęp 21.06.2019] https://pl.wikipedia.org/wiki/Drzewo_biocenotyczne [dostęp 21.06.2019] 


\title{
136 METODA WALORYZACJI DRZEW ZE WZGLĘDU NA ICH WARTOŚCI BIOCENOTYCZNE \\ Lidia Ozimkowska, Jerzy Wojtatowicz
}

\section{The method of valorisation of trees according to their biocenotic values}

\section{ABSTRACT}

The article presents a method of tree valorisation according to their biocenotic values. Three categories of descriptive and numerical evaluation of the biocenotic value of a tree were proposed. They result from individual features, connections to the immediate surroundings and location in regard to the discussed object and neighbouring ecosystems. The sum of points obtained by a tree in the three categories is the basis for qualifying to one of the biocenotic value groups.

Key words: landscape architecture, dendrology, valorisation, biocenotic values of trees, natural connections

\begin{abstract}
$\overline{\text { Lidia Ozimkowska, }}$ dr inż. arch. kraj., absolwentka Szkoły Głównej Gospodarstwa Wiejskiego w Warszawie. W latach 1982-1999 zatrudniona w Ogrodzie Botanicznym Polskiej Akademii Nauk w Warszawie - Powsinie na stanowisku projektanta, od 1995 r. współwłaścicielka pracowni projektowej Aster-Park, w latach 1995-2000 współpracowała z czasopismami "Kwietnik" $i$ "Ogrody", od 1999 pracuje jako nauczyciel akademicki w Wyższej Szkole Ekologii i Zarzq̨dzania w Warszawie, autorka monografii "Granice obiektów architektury krajobrazu", promotor kilkudziesięciu prac dyplomowych, członek SARP, PTD, rzeczoznawca NOT-SITO. Wyższa Szkoła Ekologii i Zarządzania, Warszawa, ul. Olszewska 12.

Lidia Ozimkowska, PhD, Engineer of Landscape Architecture. Graduated from the Warsaw University of Life Sciences (SGGW). Landscape designer for the Botanical Garden of the Polish Academy of Sciences in Powsin (1982-1999) and contributor to "Kwietnik" and "Ogrody" magazines (1995-2000). Co-owner of the Aster-Park design studio since 1995. An academic instructor at the University of Ecology and Management in Warsaw since 1999, she has supervised several dozen diploma projects and published a monograph entitled "Granice obiektów architektury krajobrazu" (Boundaries of Landscape Architectural Objects). Member of the Association of Polish Architects (SARP) and the Polish Dendrology Society (PTD). Appraiser with the Scientific and Technical Association of Horticultural Engineers and Technicians (NOT-SITO). University of Ecology and Management, Olszewska 12, Warszawa.
\end{abstract}

Jerzy Wojtatowicz, dr inż. arch. kraj., absolwent i wieloletni pracownik naukowy Katedry Architektury Krajobrazu Szkoły Głównej Gospodarstwa Wiejskiego w Warszawie. Od 1997 r. pracownik Wyższej Szkoły Ekologii i Zarzq̨dzania w Warszawie, (w latach 2000-2014 Dziekan Wydziału Architektury), od 1995 r. współwłaściciel pracowni projektowej Aster-Park, współautor książki „Ptaki w ogrodzie", redaktor naukowy książek: „Warszawska Przyroda. Obszary i obiekty chronione”, "Przyroda Warszawy” oraz współautor rozdziału "Zespoły przyrodniczo-krajobrazowe i tereny użytku ekologicznego" w monografii "Przyroda Bielan warszawskich”. Wyższa Szkoła Ekologii i Zarządzania, ul. Olszewska 12, Warszawa.

Jerzy Wojtatowicz, PhD, Engineer of Landscape Architecture. Graduate and long-time academic staff member of the Department of Landscape Architecture at the Warsaw University of Life Sciences (SGGW). Since 1997, he has been associated with the University of Ecology and Management in Warsaw, where he served as the Dean of the Faculty of Architecture between 2000 and 2014. He has also been running the Aster-Park design studio together with Lidia Ozimkowska since 1995. Co-author of "Ptaki w ogrodzie" (Birds in Your Garden) and a chapter on natural and landscape complexes and lands used for environmental purposes in a monograph entitled "Przyroda Bielan warszawskich" (Nature in the Warsaw District of Bielany). Science editor of two book publications: "Warszawska Przyroda. Obszary I obiekty chronione" (Warsaw's Nature. Sites and Areas Under Protection) and "Przyroda Warszawy" (Nature in Warsaw). University of Ecology and Management, Olszewska 12, Warszawa. 